\title{
Reasons for Condom Use Among Young People In KwaZulu-Natal: Prevention of HIV, Pregnancy or Both?
}

By Pranitha Maharaj

Pranitha Maharaj is senior lecturer at the School of Development Studies, University of KwaZuluNatal, Durban, South Africa.
CONTEXT: High levels of HIV/AIDS and unwanted pregnancy among young people are urgent public health problems in South Africa. Studies among youth have generally focused on protection against one or the other of these risks, but not both.

METHODS: Data collected in 2001 from 2,067 sexually active men and women aged 15-24 in KwaZulu-Natal were examined in bivariate and multivariate analyses to assess reasons for condom use, and levels and determinants of use.

RESULTS: Overall, 59\% of respondents said that they used condoms at last sexual intercourse, including $6 \%$ who used them with another method. The main reason for use (cited by $64 \%$ of users) was protection against both pregnancy and HIV infection. Two-thirds of respondents thought that becoming or making someone pregnant in the next few weeks would be a big problem; fewer than one in five viewed their risk of HIV infection as medium or high. Among both sexes, young people who would consider a pregnancy highly problematic were more likely to use condoms than their counterparts who would view a pregnancy as no problem (odds ratios, 1.4-2.3). In sharp contrast, young men and women who perceived themselves as having a medium to high risk of HIV infection were less likely to use condoms than their counterparts who perceived themselves as being at no risk (0.2-0.3).

CONCLUSION: Prevention programs could increase condom use in this population by increasing awareness of the twin risks of pregnancy and HIV infection, and by promoting condoms for protection against these dual risks.

International Family Planning Perspectives, 2006, 32(1):28-34
Young people in South Africa face high levels of unwanted pregnancy and HIV/AIDS. The South African government has cited the high incidence of unwanted pregnancy among youth as one of the major challenges facing the country. ${ }^{1}$ More than one-third of women nationally have their first child before age $20 .^{2}$ The overwhelming majority of these pregnancies occur outside marriage, and most of them are either unwanted or unplanned. ${ }^{3}$ Evidence from the $1990 \mathrm{~s}$ suggested that many young women become pregnant intentionally, to demonstrate their fertility, and return to school after the birth of their child. ${ }^{4}$ However, more recent studies have found that young women often want to avoid pregnancy at an early age. ${ }^{5}$

South Africa has one of the largest numbers of people living with HIV/AIDS of any country in the world—an estimated 4-6 million. ${ }^{6}$ The incidence of new HIV infections is highest among young people; more than half of all infected adults acquired the virus before the age of $25 .{ }^{7}$ Surveillance surveys using blood samples from women attending antenatal clinics have shown that HIV prevalence in this population increased from less than 1\% in 1990 to almost $28 \%$ in $2003 .{ }^{8}$ However, the level of infection differs notably across racial groups. In a population-based survey conducted in 2002, HIV prevalence was significantly higher among blacks than among other racial groups. ${ }^{9}$ That survey also found that the estimated HIV seroprevalence among young people aged 15-24 years in South Africa was
$9 \%$; it was $13 \%$ among women and $6 \%$ among men this age. ${ }^{10}$ As in other parts of Africa, young women in South Africa are at particularly increased risk of HIV infection. They often become infected at a younger age and at a higher rate than their male counterparts. ${ }^{11}$

In this context, the promotion of dual protectionsimultaneous protection against unwanted pregnancy and against HIV and other sexually transmitted infections (STIs) plays an important role in public health interventions. ${ }^{12}$ Apart from sexual abstinence and nonpenetrative sex, dual protection may be achieved in one of three ways: by correct and consistent use of condoms alone, by simultaneous use of condoms with another method of contraception or by use of a contraceptive method other than condoms in the context of a long-term, mutually monogamous relationship in which both partners are known to be HIV-negative (although this option may not be feasible in many settings ${ }^{13}$ ).

Among countries of Sub-Saharan Africa, South Africa has a high level of contraceptive use. According to the 1998 Demographic and Health Survey, injectables are the most commonly used method of contraception in South Africa; $30 \%$ of sexually active women use this method. ${ }^{14}$ Almost two-thirds of sexually active women aged 15-24 years use a modern contraceptive method. However, only small proportions use condoms-21\% of those aged 15-19 and 17\% of 20-24-year-olds. Hormonal implants and injectables, IUDs and sterilization are highly effective for preventing 
pregnancy, but condoms, if used correctly and consistently, are the only known method that protects sexually active individuals against the twin risks of pregnancy and HIV infection. ${ }^{15}$ The role of hormonal methods in protecting against transmission of the virus remains unclear. ${ }^{16}$ Therefore, although use of modern contraceptives in South Africa is high, current levels of HIV infection warrant greater emphasis on protection against both risks.

Some studies in South Africa have found that condom use is highly correlated with social and demographic characteristics such as age, education and race. ${ }^{17}$ In addition, research in other African settings has documented that individuals who have multiple sexual partners are more likely than others to report high levels of condom use. ${ }^{18}$ A study in Zimbabwe found that condom use increased with number of sexual partners. ${ }^{19}$ Use of this method is also highly influenced by the length and intensity of relationships: The longer a relationship lasts, the greater the likelihood that condom use will be discontinued. ${ }^{20}$ Men and women in committed relationships may prefer methods that are more effective at preventing pregnancy. However, a study in the United States found that women who perceived themselves to be at greater risk of STIs acted to protect themselves from disease as well as from pregnancy by using condoms with another method of contraception. ${ }^{21}$

Despite the magnitude of the problems of unwanted pregnancy and HIV in South Africa, relatively limited quantitative research has been conducted on the factors facilitating or inhibiting condom use (whether alone or in combination with another method), especially among young people. Much of the existing literature on young people in South Africa concentrates on factors influencing protection against the risk of unwanted pregnancy or against the risk of HIV infection-but not both. There is clearly a need to ascertain the methods young men and women use to protect themselves against both risks and the factors influencing use.

This study used data from a survey conducted in KwaZulu-Natal to examine the reasons for condom use and the level and determinants of condom use in a population with a high level of unwanted pregnancy and a severe HIV epidemic. Understanding the factors that influence condom use could inform interventions that are aimed at encouraging protective behavior to reduce the dual risks of unwanted pregnancy and HIV infection.

\section{METHODS}

\section{Survey Setting and Design}

KwaZulu-Natal, an amalgamation of the former African homeland of KwaZulu and the province of Natal, is one of the most populous provinces of South Africa, with a population of more than nine million people. The population is predominantly rural and black, and the main language spoken at home is isizulu. This province is the one most severely affected by the HIV epidemic. In 2003, 38\% of women visiting state antenatal clinics in the province were HIV-positive. ${ }^{22}$ Several socioeconomic and political factors make residents of KwaZulu-Natal particularly vulnerable to HIV infection. These include rapid urbanization, a highly mobile workforce, an international port and high levels of poverty and unemployment. ${ }^{23}$

Data for this study are from the second wave of the Transitions to Adulthood in the Context of AIDS survey, which was fielded in September-December 2001. (The survey's first wave took place in 1999. ${ }^{24}$ ) Two administrative areasthe Durban Metropolitan and Mtunzini magisterial districts-were purposely selected for the survey to ensure representation of young people from a wide range of urban, transitional and rural regions. A modified multistage cluster sample approach was used. In the first stage, 118 enumeration areas were randomly selected from a list of all census enumeration areas in the two districts. In the second stage, each selected area was divided by field supervisors into segments of approximately predetermined size. One segment was then randomly selected from each area.

In the second wave of the survey, specially trained fieldworkers visited all households within the selected segments and interviewed all willing young people aged 14-22 reported to live there. They also reinterviewed all young people who had participated in the first wave of the survey and had been aged $14-22$ at that time. ${ }^{25}$ Fieldworkers were the same sex and race as the respondents they interviewed, and spoke the respondents' preferred language.

Interviews were conducted face-to-face and were held in a private room, when possible. Respondents' answers were recorded on paper during the interviews and later entered into a database. A more comprehensive description of the fieldwork procedure and sample selection has been presented elsewhere. ${ }^{26}$

A total of 4,185 young people (1,985 males and 2,200 females) were interviewed in the second wave; the overall rate of loss to follow-up was 27\%. ${ }^{27}$ Analyses were restricted to the 2,067 young people aged 15-24 (1,029 males and 1,038 females) who reported that they had had sexual intercourse in the last 12 months.

Ethical clearance for the study was obtained from the University of Natal in South Africa. Informed consent was obtained for the individual interviews. In addition, parental consent was solicited for respondents younger than 16 .

\section{Measures}

During the interviews, respondents were asked about their social and demographic characteristics, sexual activity and contraceptive use. They were also asked to rate how much of a problem it would be if they became or made someone pregnant in the next few weeks; to rate their perceived risk of HIV infection in the next 12 months; and to answer questions assessing their knowledge of, attitudes toward and access to condoms.

Respondents were asked to name all methods that protect against unwanted pregnancy and all that protect against HIV infection. Two questions were used to determine whether condoms were used alone or in combination with another method: "The last time you had sex, did you or your partner use or do something to prevent pregnancy?" and "The 


\begin{tabular}{|c|c|c|c|}
\hline Characteristic & $\begin{array}{l}\text { Total } \\
(\mathrm{N}=2,067)\end{array}$ & $\begin{array}{l}\text { Men } \\
(\mathrm{N}=1,029)\end{array}$ & $\begin{array}{l}\text { Women } \\
(\mathrm{N}=1,038)\end{array}$ \\
\hline \multicolumn{4}{|l|}{ Age } \\
\hline $15-16$ & 9.0 & 9.5 & 8.6 \\
\hline $17-19$ & 41.0 & 42.2 & 39.8 \\
\hline $20-24$ & 50.0 & 48.3 & 51.6 \\
\hline \multicolumn{4}{|c|}{ Years of schooling } \\
\hline$<9$ & 23.6 & 23.8 & 23.4 \\
\hline$\geq 9$ & 76.4 & 76.2 & 76.7 \\
\hline \multicolumn{4}{|l|}{ Race } \\
\hline Black & 85.3 & 82.5 & 88.2 \\
\hline Other & 14.7 & 17.5 & 11.8 \\
\hline \multicolumn{4}{|c|}{ In a steady relationship } \\
\hline Yes & 81.7 & 75.6 & 87.8 \\
\hline No & 18.3 & 24.4 & 12.2 \\
\hline \multicolumn{4}{|c|}{ No. of sexual partners in last 12 mos. } \\
\hline 1 & 75.9 & 60.3 & 91.3 \\
\hline$\geq 2$ & 24.1 & 39.7 & 8.7 \\
\hline \multicolumn{4}{|c|}{ Perceived risk of HIV infection in next 12 mos. } \\
\hline None (ref) & 59.2 & 59.3 & 59.1 \\
\hline Low & 27.8 & 29.1 & 26.5 \\
\hline Medium to high & 13.0 & 11.7 & 14.4 \\
\hline \multicolumn{4}{|c|}{ Perception of pregnancy in next few weeks } \\
\hline No problem & 18.8 & 19.5 & 18.0 \\
\hline Small problem & 15.5 & 19.6 & 11.3 \\
\hline Big problem & 65.8 & 60.9 & 70.7 \\
\hline Total & 100.0 & 100.0 & 100.0 \\
\hline
\end{tabular}

last time you had sex, did you or your partner use a condom?" Respondents who reported using condoms the last time they had sex were then asked "What was the main reason you used a condom the last time you had sexual intercourse?"

\section{Analyses}

The main outcome variable was condom use, either alone or in combination with another method of contraception. Respondents who reported use of condoms at last intercourse were defined as users, and all others were defined as nonusers.

\begin{tabular}{|c|c|c|c|}
\hline Response & Total & Men & Women \\
\hline Condoms protect against HIV infection & 94.1 & 93.6 & 94.6 \\
\hline Condoms protect against pregnancy & 74.0 & $82.5^{*}$ & 65.5 \\
\hline Know of a source of condoms & 99.0 & 99.4 & 98.7 \\
\hline Can easily get condoms any time & 95.4 & 96.1 & 94.7 \\
\hline It is embarrassing to buy or ask for condoms & 12.6 & $10.8^{*}$ & 14.5 \\
\hline Using condoms reduces sexual pleasure & 34.2 & $44.4^{*}$ & 24.1 \\
\hline $\begin{array}{l}\text { When a relationship moves from casual } \\
\text { to serious, it is no longer necessary to } \\
\text { use a condom }\end{array}$ & 29.7 & 31.0 & 28.3 \\
\hline $\begin{array}{l}\text { A woman loses a man's respect if she asks } \\
\text { him to use a condom }\end{array}$ & 14.4 & 13.0 & 15.7 \\
\hline $\begin{array}{l}\text { Using a condom is a sign of not trusting } \\
\text { your partner }\end{array}$ & 23.2 & 22.1 & 24.1 \\
\hline
\end{tabular}

Factors possibly influencing condom use were selected on the basis of previous findings in the literature. ${ }^{28}$ These explanatory variables were respondents' social and demographic characteristics (age, race, years of schooling and relationship status), number of sexual partners in the past 12 months, perceptions of pregnancy and perceived risk of HIV infection.

Associations between condom use and the explanatory variables were first assessed in bivariate analysis using the chi-square test. The associations were further explored using a standard multivariate logistic regression analysis. Data were analyzed separately for men and women. All analyses were performed using SPSS.

\section{RESULTS}

\section{Sample Characteristics}

Overall and for each sex, half of respondents were aged 15-19 (Table 1). The educational level was relatively high among both sexes. Virtually all respondents had been to school, and 40\% were currently enrolled (not shown); 76\% had at least nine years of schooling. Some $85 \%$ of respondents were black.

Overall, $82 \%$ of the young people (76\% of men and $88 \%$ of women) were in a steady relationship. Most of those in such a relationship reported that their partner was a girlfriend or boyfriend, not a spouse or cohabiting partner. The majority of the sample (60\% of men and $91 \%$ of women) had had only one sexual partner in the previous 12 months. Fewer than 5\% had ever been married, and the median age at first intercourse was 16 years (not shown).

More than half of respondents (59\% of each sex) believed that they had no risk of acquiring HIV in the next year; fewer than one in six thought that they had a medium or high risk. Two-thirds of these young people (61\% of males and $71 \%$ of females) viewed the prospect of a pregnancy in the next few weeks as highly problematic.

\section{Knowledge of and Attitudes Toward Condoms}

Overall, 94\% of respondents named the condom as a method of preventing disease, and 74\% named it as a method of preventing pregnancy (Table 2). The proportion identifying use of this method as a way to avoid getting pregnant was significantly higher among men than among women (83\% vs. 66\%). By contrast, female-controlled methods for preventing pregnancy were more often identified by women than by men (not shown).

Virtually all respondents knew of a source of supply for condoms. The most commonly mentioned source was health facilities, cited by almost $94 \%$ of young people (not shown). Furthermore, access to condoms did not appear to be a problem. The vast majority of respondents (95\%) felt confident that they could easily get a condom if they needed one. Overall, $13 \%$ of young people felt that it was embarrassing to buy or ask for a condom; the proportion was significantly lower among men than among women (11\% vs. 15\%).

In general, attitudes about condoms were favorable, although sizable minorities of respondents expressed nega- 


\begin{tabular}{|lrrr|}
$\begin{array}{l}\text { TABLE 3. Percentage distribution of respondents, by method } \\
\text { used at last intercourse, according to sex }\end{array}$ & \\
Method & Total & Men & Women \\
\hline None & 30.0 & 27.1 & 32.9 \\
Condom only & 52.6 & 64.1 & 41.3 \\
Other contraceptive only & 11.4 & 5.1 & 17.6 \\
Condom with another method & 6.0 & 3.7 & 8.3 \\
Total & 100.0 & 100.0 & 100.0
\end{tabular}

tive views. Thirty-four percent of all respondents held that using condoms reduces sexual pleasure; the proportion was larger among men (44\%) than among women (24\%). Thirty percent believed that when a relationship moves from casual to serious, it is no longer necessary to use condoms. Some $14 \%$ agreed that a woman loses a man's respect if she asks him to use a condom, and 23\% felt that using a condom is a sign of not trusting one's partner.

\section{Condom Use}

In total, 59\% of young people were protected from both pregnancy and HIV the last time they had sex, $53 \%$ because they used condoms alone and $6 \%$ because they used condoms plus another method (Table 3). Some $11 \%$ were protected only from pregnancy because they used only a contraceptive method (other than the condom), and 30\% did not use any method at all. The data suggest that a higher proportion of men than of women used condoms only, and a higher proportion of women than of men used another method only.

Sixty-four percent of condom users overall used this method for dual protection against both pregnancy and STIs, including HIV (not shown); the proportion was similar among men and women (63\% and 66\%, respectively). Some $24 \%$ of male and $18 \%$ of female condom users reported using the method only for preventing pregnancy; $10 \%$ of each said that they used this method only for preventing STIs. Small proportions of men (4\%) and women (6\%) reported using condoms for other reasons (e.g., they did not trust their partner or their partner insisted on condom use).

In bivariate analyses, condom use was more prevalent among younger respondents than among their older counterparts, and black males had a lower level of use than males of other races (Table 4). Among men, condom use was more prevalent among those not in steady relationships than among others, as expected. However, the expected relationship was not observed among women. Condom use did not vary with the number of sexual partners. Contrary to expectations, use declined as perceived risk of HIV infection increased. However, the relationship between perception of pregnancy and condom use was in the expected direction. Levels of use were higher among respondents who perceived pregnancy as highly problematic than among those who viewed it as no problem.

In the multivariate analysis, among both sexes, teenagers had higher odds of using condoms than did those aged 20-24 (odds ratios, 1.5-1.7 for males and 1.4-2.0 for females), and respondents with nine or more years of school- ing had higher odds of using condoms than their less educated counterparts (3.1 and 1.7, respectively). The odds of use were higher among male respondents who were not in a steady relationship than among those who were (1.6). Young people who considered pregnancy highly problematic were more likely to use condoms than were those who believed pregnancy would not be a problem (1.4 for men and 2.3 for women); paradoxically, however, those perceiving their HIV risk as medium or high had reduced odds of using condoms ( 0.3 and 0.2 , respectively).

\section{DISCUSSION}

The traditional focus of family planning programs has been on the promotion of highly effective methods of preventing pregnancy. However, with the rapid spread of HIV, awareness that such programs can play an important role in preventing not only pregnancy but also disease has been growing. Prevention programs have increasingly promoted condom use, alone or in conjunction with another method of contraception, to protect against the risks of pregnancy and HIV infection. Knowledge of condoms is virtually universal among young people in KwaZulu-Natal, but the method is still more commonly associated with disease

\begin{tabular}{|c|c|c|c|c|}
\hline \multirow[t]{2}{*}{ Characteristic } & \multicolumn{2}{|l|}{ Men } & \multicolumn{2}{|c|}{ Women } \\
\hline & $\%$ & $\begin{array}{l}\text { Odds } \\
\text { ratio }\end{array}$ & $\%$ & $\begin{array}{l}\text { Odds } \\
\text { ratio }\end{array}$ \\
\hline \multicolumn{5}{|l|}{ Age } \\
\hline $15-16$ & $66.3^{*}$ & $1.66^{*}$ & $59.6^{*}$ & $1.99 *$ \\
\hline 17-19 & 70.0 & $1.52^{*}$ & 53.4 & $1.43^{*}$ \\
\hline 20-24 (ref) & 65.4 & 1.00 & 45.0 & 1.00 \\
\hline \multicolumn{5}{|l|}{ Race } \\
\hline Black & $66.0^{*}$ & 1.03 & 50.2 & 1.51 \\
\hline Other (ref) & 74.4 & 1.00 & 45.1 & 1.00 \\
\hline \multicolumn{5}{|c|}{ Years of schooling } \\
\hline$<9$ (ref) & 51.4 & 1.00 & 43.6 & 1.00 \\
\hline$\geq 9$ & $72.4^{*}$ & $3.12^{*}$ & $51.5^{*}$ & $1.68^{*}$ \\
\hline \multicolumn{5}{|c|}{ In a steady relationship } \\
\hline Yes (ref) & 65.0 & 1.00 & 49.9 & 1.00 \\
\hline No & $74.9^{*}$ & $1.64^{*}$ & 47.6 & 0.95 \\
\hline \multicolumn{5}{|c|}{$\begin{array}{l}\text { No. of sexual partners } \\
\text { in last } 12 \text { mos. }\end{array}$} \\
\hline 1 (ref) & 68.3 & 1.00 & 49.7 & 1.00 \\
\hline$\geq 2$ & 66.2 & 1.10 & 48.9 & 1.30 \\
\hline \multicolumn{5}{|c|}{$\begin{array}{l}\text { Perceived risk of HIV infection } \\
\text { in next } 12 \text { mos. }\end{array}$} \\
\hline None (ref) & 71.7 & 1.00 & 56.6 & 1.00 \\
\hline Low & 69.0 & 0.86 & 49.1 & $0.70^{*}$ \\
\hline Medium to high & $41.2^{*}$ & $0.25^{*}$ & $24.5^{*}$ & $0.23^{*}$ \\
\hline \multicolumn{5}{|c|}{$\begin{array}{l}\text { Perception of pregnancy } \\
\text { in next few weeks }\end{array}$} \\
\hline No problem & 60.0 & 1.00 & 34.1 & 1.00 \\
\hline Small problem & 68.2 & 1.41 & 53.0 & $2.20^{*}$ \\
\hline Big problem & $69.6^{*}$ & $1.39 *$ & $53.5^{*}$ & $2.25^{*}$ \\
\hline
\end{tabular}


prevention than with pregnancy prevention. The challenge for reproductive health programs is to emphasize the dual protective benefits of correct and consistent condom use and, more specifically, the role of this method in preventing pregnancy.

Knowledge of condoms is obviously a necessary, if not sufficient, condition for their acceptance and use. But beliefs about condoms, both positive and negative, also are likely to influence use. ${ }^{29}$ Other studies have found that numerous beliefs about condoms - including that they are used only for illicit sex and prostitution, they are difficult to use and they reduce sexual pleasure-have limited their ac-

Reproductive

health programs

...need to

create greater

awareness of

the risks of

pregnancy and

HIV infection,

and provide

counseling on

these risks. ceptability and use. ${ }^{30}$ The results of this study are, to some extent, encouraging. Overall, attitudes toward condoms were relatively positive, suggesting that even though young people in South Africa have concerns about condoms, the method may be gaining acceptance.

Use of a second method in addition to condoms was uncommon in this sample of young people. This finding is consistent with results of studies conducted in other countries, which have found that young people prefer to use a single method. ${ }^{31}$ The majority of respondents using condoms did so for dual purposes - prevention of both pregnancy and HIV infection. However, roughly one-third used condoms for only a single purpose. Condoms were the main method of choice for preventing pregnancy among both sexes. This finding is encouraging, given the dual protective benefits of this method, but it contrasts sharply with results of other studies conducted in South Africa, which have found a greater reliance on hormonal methods for preventing pregnancy, particularly among older people in long-term, ongoing relationships. ${ }^{32}$ Consistent with previous research, the current study suggests that condom use is more prevalent among men who are not in a steady sexual partnership than among others. Men may compensate for risky sexual behavior by using condoms. ${ }^{33}$ However, the results suggest that more research is needed among young people to investigate what happens to condom use when a relationship becomes serious.

Both sexes thought that a pregnancy in the near future would be highly problematic. This perception, in turn, emerged as an important positive determinant of condom use. This suggests that among both sexes, a desire to avoid pregnancy and its consequences was a strong motivator of use. A growing number of studies in South Africa similarly show that young women are deeply worried about becoming pregnant at an early age and, as a result, are willing to take precautions to protect themselves against this risk. ${ }^{34}$

One would expect that among sexually active young people, the level of condom use will increase as the perceived risk of HIV infection increases. However, in the multivariate analysis, a higher perceived risk of acquiring HIV emerged as a negative determinant of condom use. This finding has several possible explanations: Young people may feel that they have no control over their risk and thus feel little motivation to use condoms. Or they may feel that with the increasing availability of antiretroviral therapy, they need not be as careful about their risk-related behavior. Additionally, unmeasured factors probably have influenced condom use. In another study, higher perceived vulnerability to HIV infection among South African youth was associated with greater intended and actual condom use. ${ }^{35}$ In the current study, young people of both sexes tended to perceive their risk of contracting the virus as low. Their use of condoms may well have reduced their perceived vulnerability. Obviously, the magnitude of the AIDS epidemic in KwaZulu-Natal requires an intensified response in addressing awareness. Interventions can play a major role in raising awareness of the risk of HIV infection among young people. Indeed, the increasing availability of antiretroviral therapy and the expansion of voluntary counseling and testing facilities are also likely to contribute to a more accurate assessment of risk of HIV infection as growing numbers of people ask to be tested.

The study's findings may have limited generalizability to other populations because the sample was drawn from a single province in South Africa. Interpretation of the findings is limited by the focus on condom use at last sexual intercourse. In addition, social desirability probably altered the reporting of condom use to some extent. The desire to appear to hold contemporary views and to approve of condoms is likely to influence reported use. ${ }^{36}$ Social desirability bias likely occurs in settings where there is extensive publicity in favor of contraception. ${ }^{37}$ Desire for privacy, embarrassment and fear of reprisals are some of the reasons that may motivate people to conceal their true sexual behavior. ${ }^{38} \mathrm{Fi}$ nally, as the analyses rely on cross-sectional data, the direction of causality cannot be determined.

The findings of this study suggest that reproductive health programs will need to create greater awareness of the risks of pregnancy and HIV infection, and provide counseling on these risks. This study was conducted in a setting where the case for condom use for dual protection is particularly strong. The level of unwanted pregnancy among young people in South Africa is high, and the risk of HIV infection is among the highest in all of Sub-Saharan Africa. ${ }^{39}$ Traditionally, pregnancy prevention and disease prevention have been addressed separately, but given the role of condoms in protecting against both risks, providers should address them as interrelated. Specifically, providers should focus their counseling on correct and consistent condom use in combination with use of another contraceptive. Directly addressing the dual risks of pregnancy and HIV infection, and young people's desire to avoid these outcomes, may dramatically improve the level of condom use.

\section{REFERENCES}

1. Department of Welfare and Population Development, Population Policy for South Africa, Pretoria, South Africa: Department of Welfare and Population Development, 1998.

2. Department of Health of South Africa and Macro International, South Africa Demographic and Health Survey 1998, Pretoria, South Africa, and Calverton, MD, USA: Medical Research Council and Macro International, 1999 
3. Ibid.

4. Preston-Whyte E and Zondi M, African teenage pregnancy: whose problem? in: Burman S and Preston-Whyte E, eds., Questionable Issue: Illegitimacy in South Africa, Cape Town, South Africa: Oxford University Press, 1992; and Buga G et al., Sexual behaviour, contraceptive practice and reproductive health among school adolescents in rural Transkei, South African Medical Journal, 1996, 86(5):523-527

5. Kaufman C et al., Adolescent pregnancy and parenthood in South Africa, Studies in Family Planning, 2001, 32(2):147-160; and Rutenberg N et al., Pregnant or positive: adolescent childbearing and HIV risk in KwaZulu Natal, South Africa, Reproductive Health Matters, 2003, 11(22):122-133.

6. Ijumba P et al., Access to antiretroviral therapy, in: Ijumba P, Day C and Ntuli A, South African Health Review 2003/2004, Durban, South Africa: Health Systems Trust, 2004.

7. Steinberg M et al., HIV/AIDS: facts, figures and the future, in: South African Health Review 2000, Durban, South Africa: Health Systems Trust, 2001; and LoveLife, The Impending Catastrophe: A Resource Book on the Emerging HIV/AIDS Epidemic in South Africa, Johannesburg, South Africa: LoveLife and Henry J. Kaiser Family Foundation, 2000.

8. Department of Health of South Africa, National HIV and Syphilis Sero-Prevalence Survey of Women Attending Public Antenatal Clinics in South Africa, Pretoria, South Africa: Department of Health of South Africa, 2004.

9. Mandela Foundation and Human Sciences Research Council (HSRC), South African National HIV Prevalence, Behavioural Risks and Mass Media: Household Survey 2002, Cape Town, South Africa: HSRC, 2002.

10. Ibid.

11. Harrison A et al., Understanding young women's risk for HIV/AIDS: adolescent sexuality and vulnerability in rural KwaZulu/Natal, Society in Transition, 2001, 32(1):79-82.

12. Myer L et al., Dual method use in South Africa, International Family Planning Perspectives, 2002, 28(2):119-121.

13. Mantell J et al., Family planning providers' perspectives on dual protection, Perspectives on Sexual and Reproductive Health, 2003, 35(2):71-78.

14. Department of Health of South Africa and Macro International, 1999, op. cit. (see reference 2).

15. Wright K, Dual protection, Network, 2003, 22(4):12-15.

16. Cates W and Steiner M, Dual protection against unintended pregnancy and sexually transmitted infections, Sexually Transmitted Diseases, 2002, 29(3):168-173.

17. Morroni $C$ et al., Dual protection against sexually transmitted infections and pregnancy in South Africa, African Journal of Reproductive Health, 2003, 7(2):13-19; and Myer Let al., 2002, op. cit. (see reference 12).

18. Adetunji J and Meekers D, Consistency of condom use in the context of AIDS in Zimbabwe, Journal of Biosocial Science, 2001, 33(1):121-138; and Kapiga S et al., Predictors of AIDS knowledge, condom use and high risk sexual behavior among women in Dares-Salaam, Tanzania, International Journal of STD and AIDS, 1995 , 6(3):175-183.

19. Adetunji J and Meekers D, 2001, op. cit. (see reference 18).

20. Anderson J et al., Condom use and HIV risk behaviors among U.S. adults: data from a national survey, Family Planning Perspectives, 1999, 31(1):24-28

21. Poppen P and Reisen C, Women's use of dual methods of sexual protection, Women and Health, 1999, 30(2):53-67.

22. Department of Health of South Africa, 2004, op. cit. (see reference 8).

23. Whiteside A et al., AIDS-The Impact of HIV/AIDS on Planning Issues in KwaZulu Natal, Pietermaritzburg, South Africa: Town and Regional Planning Commission, 1995.
24. Rutenberg N et al., Transitions to Adulthood in the Context of AIDS in South Africa: Report of Wave 1, New York: Population Council, 2001.

25. Magnani R et al., The impact of life skills education on adolescent sexual risk behavior in KwaZulu-Natal, South Africa, Journal of Adolescent Health, 2005, 36(4):289-304.

26. Ibid.

27. Transitions to Adulthood Study Team, The Transition to Adulthood in the Context of AIDS in South Africa: The Impact of Exposure to Life Skills Education on Adolescent Knowledge, Skills and Behavior, Washington, DC: Population Council, 2004

28. Morroni C et al., 2003, op. cit. (see reference 17); and Myer L et al., 2002, op. cit. (see reference 12).

29. Adetunji J and Meekers D, 2001, op. cit. (see reference 18); and Kapiga S et al., 1995, op. cit. (see reference 18).

30. Mehryar A, Condoms: awareness, attitudes and use, in: Cleland J et al., eds., Sexual Behaviour and AIDS in the Developing World, London: Taylor and Francis, 1995; Nzioka C, Factors influencing male interest in family planning in Kenya, African Journal of Reproductive Health, 1998, 11(2):122-141; MacPhail C and Campbell C, 'I think condoms are good but, aai, I hate those things': condom use among adolescents and young people in a Southern African township, Social Science \& Medicine, 2001, 52(11):1613-1627; and Varga $C$, South African young people's sexual dynamics: implications for behavioural responses to HIV/AIDS, in: Caldwell J et al., eds., Resistance to Behavioural Change to Reduce HIV/AIDS Infection, Canberra, Australia: Health Transition Centre, National Centre for Epidemiology and Population Health, 1999.

31. Cushman L et al., Condom use among women choosing longterm hormonal contraception, Family Planning Perspectives, 1998, 30(5):240-243; and Santelli J et al., The use of condoms with other contraceptive methods among young men and women, Family Planning Perspectives, 1997, 29(6):261-267.

32. Kleinschmidt I et al., Dual protection in sexually active women, South African Medical Journal, 2003, 93(11):854-857; and Maharaj $\mathrm{P}$ and Cleland J, Condom use within marital and cohabiting partnerships in KwaZulu-Natal, South Africa, Studies in Family Planning, 2004, 35(2):116-124.

33. Evans B et al., Sexual relationships, risk behavior, and condom use in the spread of sexually transmitted infections to heterosexual men, Genitourinary Medicine, 1997, 73(5):368-372.

34. Kaufman C et al., 2001, op. cit. (see reference 5); Rutenberg N et al., 2003, op. cit. (see reference 5); and Varga C, Pregnancy termination among South African adolescents, Studies in Family Planning, 2002, 33(4):283-298.

35. Peltzer K, Factors affecting condom use in an urban adult community of the Northern Province, South Africa, Journal of Psychology in Africa, 1999, 9:66-77.

36. Catania J et al., Methodological problems in AIDS behavioral research: influences on measurement error and participation bias in studies of sexual behavior, Psychological Bulletin, 1990, 108(3): 339-362.

37. Zenilman J et al., Condom use to prevent STDs: the validity of self-reported condom use, Sexually Transmitted Diseases, 1995, 22(1):15-21.

38. Catania J et al., 1990, op. cit. (see reference 36).

39. Joint United Nations Programme on HIV/AIDS (UNAIDS), AIDS Epidemic Update: December 2005, Geneva: UNAIDS, 2005.

\section{RESUMEN}

Contexto: Los elevados niveles del VIH/SIDA y del embarazo no deseado entre los jóvenes de Sudáfrica son problemas de salud pública que requieren urgente atención. Los estudios realizados entre los jóvenes en general han concentrado la atención en la protección contra uno de estos riesgos, pero no contra ambos al mismo tiempo. 
Métodos: Los datos recopilados en 2001 de 2.067 hombres y mujeres sexualmente activos, de 15-24 años de edad, en KwaZulu-Natal fueron examinados mediante análisis bivariados y multivariados para evaluar las razones por las cuales se usaban el condón y los niveles y determinantes de su uso.

Resultados: En general, el 59\% de los entrevistados indicaron que habian usado un condón durante su última relación sexual, incluido el 6\% que habían usado el condón junto con otro método. La principal razón para el uso del condón (mencionado por el 64\% de los usuarios) fue para protegerse de un posible embarazo y también de una infección del VIH. Aproximadamente el $66 \%$ de los entrevistados consideraron que quedar embarazada o hacer que alguien quede embarazada en las próximas semanas constituiría un enorme problema; el 13\% consideró que su riesgo de contraer el VIH era un riesgo medio o elevado. Entre ambos sexos, los jóvenes que consideraban que un embarazo era sumamente problemático eran más proclives a usar un condón que sus contrapartes que consideraban que un embarazo no era un problema (razones de momios de 1,4-2,3). En forma muy diferente, los hombres y mujeres jóvenes que consideraban que corrían un riesgo medio o elevado de contraer la infección del VIH fueron menos proclives a usar un condón que sus contrapartes que no percibieron que corrían gran riesgo $(0,2-0,3)$.

Conclusión: Los programas de prevención podrían incrementar el uso del condón entre esta población joven si aumentan el nivel de concienciación con respecto a los dos riesgos, del embarazo y de la infección del VIH, y si promueven el uso del condón para protegerse contra estos dos riesgos.

\section{RÉSUMÉ}

Contexte: Les hauts niveaux de VIH/SIDA et de grossesse non désirée parmi les jeunes posent des problèmes pressants de santé publique en Afrique du Sud. Les études menées parmi les jeunes se concentrent généralement sur la protection contre l'un ou l'autre de ces risques, mais pas les deux.
Méthodes: Les données recueillies en 2001 auprès de 2.067 hommes et femmes sexuellement actifs de 15 à 24 ans au KwaZulu-Natal ont été examinées dans le cadre d'analyses biet multivariées afin d'évaluer les raisons de l'usage du préservatif et les niveaux et déterminants de cet usage.

Résultats: Dans l'ensemble, 59\% des répondants ont déclaré avoir utilisé le préservatif lors de leurs derniers rapports sexuels, y compris 6\% l'ayant utilisé en combinaison avec une autre méthode. La raison principale d'usage (citée par 64\% des utilisateurs) s'est avérée la protection, à la fois, contre la grossesse et l'infection à VIH. Quelque 66\% des répondants estimaient que se retrouver, ou mettre une partenaire enceinte au cours des quelques semaines à venir poserait un gros problème; $13 \%$ ont qualifié leur risque d’infection à VIH de moyen ou élevé. Dans les deux sexes, les jeunes qui percevraient une grossesse comme fort problématique sont apparus plus susceptibles d'utiliser le préservatif que leurs homologues pour lesquels une grossesse ne poserait pas de problème (rapports de probabilités 1,4-2,3). Le contraste est net avec les jeunes hommes et femmes qui percevaient leur risque d'infection à VIH comme moyen ou élevé, en ce qu'ils sont moins susceptibles d'utiliser le préservatif que leurs homologues ne percevant aucun risque $(0,2-0,3)$.

Conclusion: Les programmes de prévention pourraient accroître l'usage du préservatif au sein de cette population en la sensibilisant davantage au double risque de grossesse et d'infection à $V I H$, ainsi qu'en présentant davantage le préservatif en tant que protection contre les deux risques.

\section{Acknowledgments}

The author thanks Naomi Rutenberg for her comments on early drafts of the article. The study was supported by the Rockefeller Foundation and the U.S. Agency for International Development through the Horizons Program, the Focus on Young Adults Project and the MEASURE/Evaluation Project.

Author contact: Maharajp7@ukzn.ac.za 